\title{
Pseudomonas mosselii sp. nov., a novel species isolated from clinical specimens
}

\author{
${ }^{1}$ Laboratoire de \\ Bactériologie-Hygiène, \\ Hôpital Calmette, \\ Boulevard du Professeur J. \\ Leclercq, 59037 Lille Cedex, \\ France \\ 2 Service de Microbiologie, \\ Faculté de Pharmacie, \\ 3 rue du Professeur \\ Laguesse, BP 83, 59006 \\ Lille Cedex, France \\ ${ }^{3}$ Laboratoire de \\ Microbiologie et de \\ Génétique, Université \\ Louis-Pasteur, UPRES-A \\ 7010, F-67000 Strasbourg, \\ France
}

\author{
Fouad Dabboussi, ${ }^{1}$ Monzer Hamze, ${ }^{1}$ Elisabeth Singer, ${ }^{2}$ Valerie Geoffroy, ${ }^{3}$ \\ Jean-Marie Meyer ${ }^{3}$ and Daniel Izard ${ }^{1,2}$
}

Author for correspondence: Daniel Izard. Tel: + 333207885 01. Fax: + 33320397244 . e-mail: daniel.izard@wanadoo.fr

\begin{abstract}
Twenty-two fluorescent pseudomonad strains of clinical origin received as Pseudomonas fluorescens (10 strains), Pseudomonas putida (10 strains) and Pseudomonas sp. (2 strains), and 33 type strains of the genus Pseudomonas were studied by numerical analysis based on 280 phenotypic characters. Twelve of the 22 clinical isolates clustered within a specific group, cluster IV. The other strains clustered within groups containing well-characterized fluorescent Pseudomonas species or did not cluster. Strains belonging to cluster IV were phenotypically different from all other clusters and subclusters of fluorescent pseudomonads. DNA-DNA hybridization showed that cluster IV corresponded to a genomic group sharing $72-100 \%$ DNA relatedness. DNA-DNA hybridization values with 67 strains representing $\mathbf{3 0}$ species of the genus Pseudomonas sensu stricto, including six recently described species (Pseudomonas veronii, Pseudomonas rhodesiae, Pseudomonas libanensis, 'Pseudomonas orientalis', ' Pseudomonas cedrella' and Pseudomonas monteilii), were below $49 \%$, the value found for $P$. monteilii. The DNA G+C content of the type strain was $63 \mathrm{~mol} \%$. Comparison of the 16S rRNA gene sequence of a representative strain of cluster IV (CFML 90-83') with sequences of other strains of the genus Pseudomonas revealed that strain CFML 90-83' was part of the $P$. fluorescens intrageneric cluster. On the basis of phenotypic, DNA-DNA hybridization and phylogenetic analyses, a novel species, Pseudomonas mosselii sp. nov., is proposed for the 12 strains of cluster IV. The type strain is $P$. mosselii CFML 90-83' (= ATCC BAA-99 ${ }^{\top}=$ CIP 105259'). The $P$. mosselii strains are phenotypically homogeneous and can be differentiated from other fluorescent species by several phenotypic features, including pyoverdine typing.
\end{abstract}

Keywords: Pseudomonas, DNA-DNA hybridization, 16S rRNA, siderotyping

\section{INTRODUCTION}

The genus Pseudomonas includes metabolically versatile organisms utilizing a wide range of organic compounds (Stanier et al., 1966). These bacteria are ubiquitous in soil and water and some are also important as plant, animal and human pathogens (Pal-

\footnotetext{
Abbreviations: IEF, isoelectrofocusing; $K_{\text {nuc }}$ nucleotide substitution rate; $\mathrm{pH}_{\mathrm{i}}$, isoelectric $\mathrm{pH}$; SD, Dice coefficient; $T_{\mathrm{m}}$, temperature at which $50 \%$ reassociated DNA is hydrolysed by nuclease $S 1 ; \Delta T_{m}$, difference between heteroduplex $T_{\mathrm{m}}$ and homoduplex $T_{\mathrm{m}}$.

The EMBL accession number for the 165 rRNA gene sequence of strain CFML $90-83^{\top}$ is AF072688.
}

leroni, 1992). The nomenclature of bacteria classified in the genus Pseudomonas has changed considerably during the last decade. By measuring the similarities of various Pseudomonas species by rRNA-DNA hybridization, Palleroni et al. (1973) were able to subdivide the genus into five distantly related so-called rRNA groups (rRNA groups I-V). Genuine Pseudomonas species are currently restricted to taxa belonging or related to rRNA group I of Palleroni (De Vos \& De Ley, 1983; De Vos et al., 1989; Palleroni \& Bradbury, 1993; Segers et al., 1994; Willems et al., 1992; Yabuuchi et al., 1992). Species of Pseudomonas sensu lato have been classified into several genera: Pseudomonas sensu stricto, Chryseomonas, Flavimonas (Holmes et 
Table 1. List of organisms studied and their classification based on phenotypic analysis

\begin{tabular}{|c|c|c|c|c|}
\hline $\begin{array}{l}\text { Culture collection or } \\
\text { other reference } \\
\text { number* }\end{array}$ & Name as received & Source & Cluster $\dagger$ & Subcluster $\dagger$ \\
\hline NCPPB 1616 & P. tolaasii & Cultivated mushroom Agaricus bisporus & I & \\
\hline NCPPB $2192^{\mathrm{T}}$ & P. tolaasii & Cultivated mushroom Agaricus bisporus & I & \\
\hline ATCC $13525^{\mathrm{T}}$ & P. fluorescens biovar I & Pre-filter & I & \\
\hline ATCC 17563 & P. fluorescens biovar I & Tap water & I & \\
\hline CFML 90-132 & P. fluorescens & Sputum & II & \\
\hline ATCC $10844^{\mathrm{T}}$ & P. marginalis & Endive & II & \\
\hline DSM 50275 & P. marginalis & Plant & II & \\
\hline DSM 50276 & P. marginalis & Soft rot of potato tuber & II & \\
\hline DSM 50106 & P. fluorescens biovar II & Sea water & II & \\
\hline ATCC $12633^{\mathrm{T}}$ & P. putida biovar A & Tracheal aspirate & III & IIIa \\
\hline CFML 90-42 & P. putida & Placenta & III & IIIa \\
\hline CFML 90-46 & P. putida & Sputum & III & IIIa \\
\hline CFML 90-47 & P. putida & Urine & III & IIIa \\
\hline CFML 90-49 & P. putida & Urine & III & IIIa \\
\hline CFML 90-52 & P. putida & Infected skin & III & IIIa \\
\hline CFML 90-39 & P. putida & Suppuration & III & IIIa \\
\hline CFML 90-40 & P. putida & Bronchial aspirate & III & IIIa \\
\hline CIP $104883^{\mathrm{T}}$ & P. monteilii & Clinical isolate & III & IIIb \\
\hline CFML 90-59 & P. monteilii & Clinical isolate & III & IIIb \\
\hline CFML 90-60 & P. monteilii & Bronchial aspirate & III & IIIb \\
\hline CFML 90-61 & P. monteilii & Bronchial aspirate & III & IIIb \\
\hline CFML 90-62 & P. monteilii & Urine & III & IIIb \\
\hline CFML 90-41 & P. putida & Urine & III & $\mathrm{NC}$ \\
\hline CFML $90-83^{\mathrm{T}}$ & P. putida & Tracheal aspirate & IV & \\
\hline CFML 90-70 & P. fluorescens & Bronchial aspirate & IV & \\
\hline CFML 90-71 & P. fluorescens & Blood culture & IV & \\
\hline CFML 90-73 & P. fluorescens & Veinous catheter & IV & \\
\hline CFML 90-74 & P. fluorescens & Stool & IV & \\
\hline CFML 90-75 & Pseudomonas sp. & Drainage liquid & IV & \\
\hline CFML 90-76 & Pseudomonas sp. & Faeces & IV & \\
\hline CFML 90-77 & P. fluorescens & Bronchial aspirate & IV & \\
\hline CFML 90-78 & P. fluorescens & Clinical isolate & IV & \\
\hline CFML 90-79 & P. fluorescens & Clinical isolate & IV & \\
\hline CFML 90-80 & P. fluorescens & Clinical isolate & IV & \\
\hline CFML 90-82 & P. fluorescens & Clinical isolate & IV & \\
\hline ATCC $13985^{\mathrm{T}}$ & P. aureofaciens & Mass river clay in kerosene & $\mathrm{V}$ & \\
\hline DSM $50083^{\mathrm{T}}$ & P. chlororaphis & Plate contaminant & $\mathrm{V}$ & \\
\hline CCUG 1317 & P. putida biovar B & Soil & VI & \\
\hline ATCC 17430 & P. putida biovar B & Soil & VI & \\
\hline ATCC $10145^{\mathrm{T}}$ & P. aeruginosa & Infected wound & VII & \\
\hline ATCC 27853 & $P$. aeruginosa & Blood culture & VII & \\
\hline ATCC 17559 & P. fluorescens biovar III & Plant & VIII & \\
\hline ATCC 17571 & P. fluorescens biovar III & Polluted sea water & VIII & \\
\hline CCM $573^{\mathrm{T}}$ & P. lundensis & Beef meat & IX & \\
\hline CCUG 18758 & P. lundensis & Beef meat & IX & \\
\hline NCPPB $1873^{\mathrm{T}}$ & P. caricapapayae & Unknown & $\mathrm{NC}$ & \\
\hline ATCC $19310^{\mathrm{T}}$ & P. syringae & Plant & $\mathrm{NC}$ & \\
\hline CCUG $1313^{\mathrm{T}}$ & P. fragi & Unknown & $\mathrm{NC}$ & \\
\hline DSM $50259^{\mathrm{T}}$ & P. cichorii & Endive & $\mathrm{NC}$ & \\
\hline ATCC $25941^{\mathrm{T}}$ & P. agarici & Unknown & $\mathrm{NC}$ & \\
\hline ATCC $23835^{\mathrm{T}}$ & P. asplenii & Plant & $\mathrm{NC}$ & \\
\hline DSM 50148 & P. fluorescens biovar $\mathrm{V}$ & Soil & $\mathrm{NC}$ & \\
\hline
\end{tabular}


Table 1 (cont.)

\begin{tabular}{|llll|}
\hline $\begin{array}{l}\text { Culture collection or } \\
\text { other reference } \\
\text { number* }\end{array}$ & Name as received & Source & Cluster $\dagger$ \\
\hline ATCC 17815 & P. fluorescens biovar II & Lettuce & NC \\
CFML $90-65$ & $P$. putida & Urine & NC \\
DSM 50415 & $P$. fluorescens biovar IV & Unknown & NC \\
\hline
\end{tabular}

* ATCC, American Type Culture Collection, Manassas, VA, USA; DSM, Deutsche Sammlung von Mikroorganismen und Zellkulturen GmbH, Braunschweig, Germany; NCPPB, National Collection of Plant-Pathogenic Bacteria, Plant Pathology Laboratory, Hatching Green, Harpenden, UK; CIP, Collection de l'Institut Pasteur, Paris, France; CCUG, Culture Collection, University of Göteborg, Göteborg, Sweden; CCM, Czechoslovak Collection of Microorganisms, J. E. Purkyne, University, Brno, Czech Republic; CFML, Collection de la Faculté de Médecine de Lille, Lille, France.

$\dagger$ NC, Strain does not belong to any major phenotypic cluster or subcluster as defined by numerical analysis.

al., 1987), Burkholderia (Yabuuchi et al., 1992), Ralstonia (Yabuuchi et al., 1995), Comamonas (De Vos et al., 1985), Acidovorax (Willems et al., 1990), Hydrogenophaga (Willems et al., 1989), Telluria (Bowman et al., 1993), Stenotrophomonas (Palleroni \& Bradbury, 1993), Brevundimonas (Segers et al., 1994), Aminobacter (Urakami et al., 1992), Oligotropha, Zavarzinia (Meyer et al., 1993), Sphingomonas (Yabuuchi et al., 1990), Devosia (Nakagawa et al., 1996) and Delftia (Wen et al., 1999). The genus Pseudomonas sensu stricto consists of both fluorescent and non-fluorescent species. The fluorescent pseudomonads are characterized by the production of water-soluble pigments, the pyoverdines, which act as powerful siderophores for these bacteria (Meyer \& Stintzi, 1998). Most of the fluorescent species are saprophytic (e.g. Pseudomonas fluorescens) or pathogenic for humans (e.g. Pseudomonas aeruginosa), plants (e.g. Pseudomonas cichorii, Pseudomonas marginalis, Pseudomonas syringae, Pseudomonas savastanoi) or mushrooms (e.g. Pseudomonas agarici, Pseudomonas tolaasii).

Detailed phenotypic, chemotaxonomic or genotypic studies indicate that $P$. fluorescens and Pseudomonas putida are heterogeneous Pseudomonas species (Vancanneyt et al., 1996). Strains of $P$. putida and $P$. fluorescens are very common environmental contaminants and these organisms are rarely pathogenic for humans, even though they have been found associated with urinary tract infections, septicaemia, septic arthritis, osteomyelitis, wound infections, pelvic inflammatory disease and various other diseases (Palleroni, 1992). There are also numerous references reporting their isolation from a variety of materials of clinical origin (Blazevic et al., 1973; Gilardi, 1972; Pedersen et al., 1970; Rogers, 1960; Sutter, 1968). In any event, $P$. putida and $P$. fluorescens should be considered potentially pathogenic (Von Graevenitz \& Weinstein, 1971).

This study was intended to provide a phenotypic, genotypic and phylogenetic analysis of 22 strains of clinical origin related to $P$. putida, P. fluorescens and Pseudomonas sp. From this study, a novel species, Pseudomonas mosselii sp. nov., is formally described; the type strain is CFML $90-83^{\mathrm{T}}$ (= ATCC BAA-99 $9^{\mathrm{T}}=$ CIP $105259^{\mathrm{T}}$ ).

\section{METHODS}

Bacterial strains. A total of 89 strains was used in this study. Twenty-two strains were isolated from clinical specimens, received as $P$. putida (10 strains), P. fluorescens (10 strains) and Pseudomonas sp. (2 strains). Sixty-seven strains were used as references for numerical taxonomy and DNA-DNA hybridization studies, representing 30 species of the genus Pseudomonas sensu stricto (Kersters et al., 1996), including 6 newly described Pseudomonas species: Pseudomonas veronii (Elomari et al., 1996), Pseudomonas rhodesiae (Coroler et al., 1996), both isolated from French mineral waters, Pseudomonas monteilii (Elomari et al., 1997) isolated from clinical specimens, and 'Pseudomonas cedrella', 'Pseudomonas orientalis' (Dabboussi et al., 1999a) and Pseudomonas libanensis (Dabboussi et al., 1999b) isolated from Lebanese spring waters (Table 1). All bacteria were cultured routinely on Mueller-Hinton medium at $30^{\circ} \mathrm{C}$.

Phenotypic characterization. Two-hundred-and-eighty phenotypic characters were determined. Forty-four conventional tests were performed as described by Gavini et al. (1989). Assimilation of 147 compounds, including carbohydrates, organic acids and amino acids, as sole carbon source was tested using API 50-CH, API 50-AO and API 50-AA galleries (bioMérieux); growth was observed after 2, 4 and $6 \mathrm{~d}$, respectively. Eighty-nine enzymic activities, including 59 peptidase, 10 esterase and 20 oxidase activities, were tested as described previously (Gavini et al., 1991). These tests were also studied with the API system (API ZYM; bioMérieux), incubated at $30^{\circ} \mathrm{C}$ for $4 \mathrm{~h}$. They were scored according to the manufacturer's recommendations. Tests which were either positive or negative for all the strains were not included in the numerical analysis; other data were coded 1 for positive results, 0 for negative results and subjected to numerical analysis as described by Gavini et al. (1989).

Numerical taxonomic analysis. Based on a matrix containing 55 strains and 230 tests, the Dice coefficient (SD) for each pair of strains was obtained as follows: $\mathrm{SD}=2 a /(2 a+b+$ 
SD

$\begin{array}{lllllllllll}0 & 10 & 20 & 30 & 40 & 50 & 60 & 70 & 80 & 90 & 100 \%\end{array}$

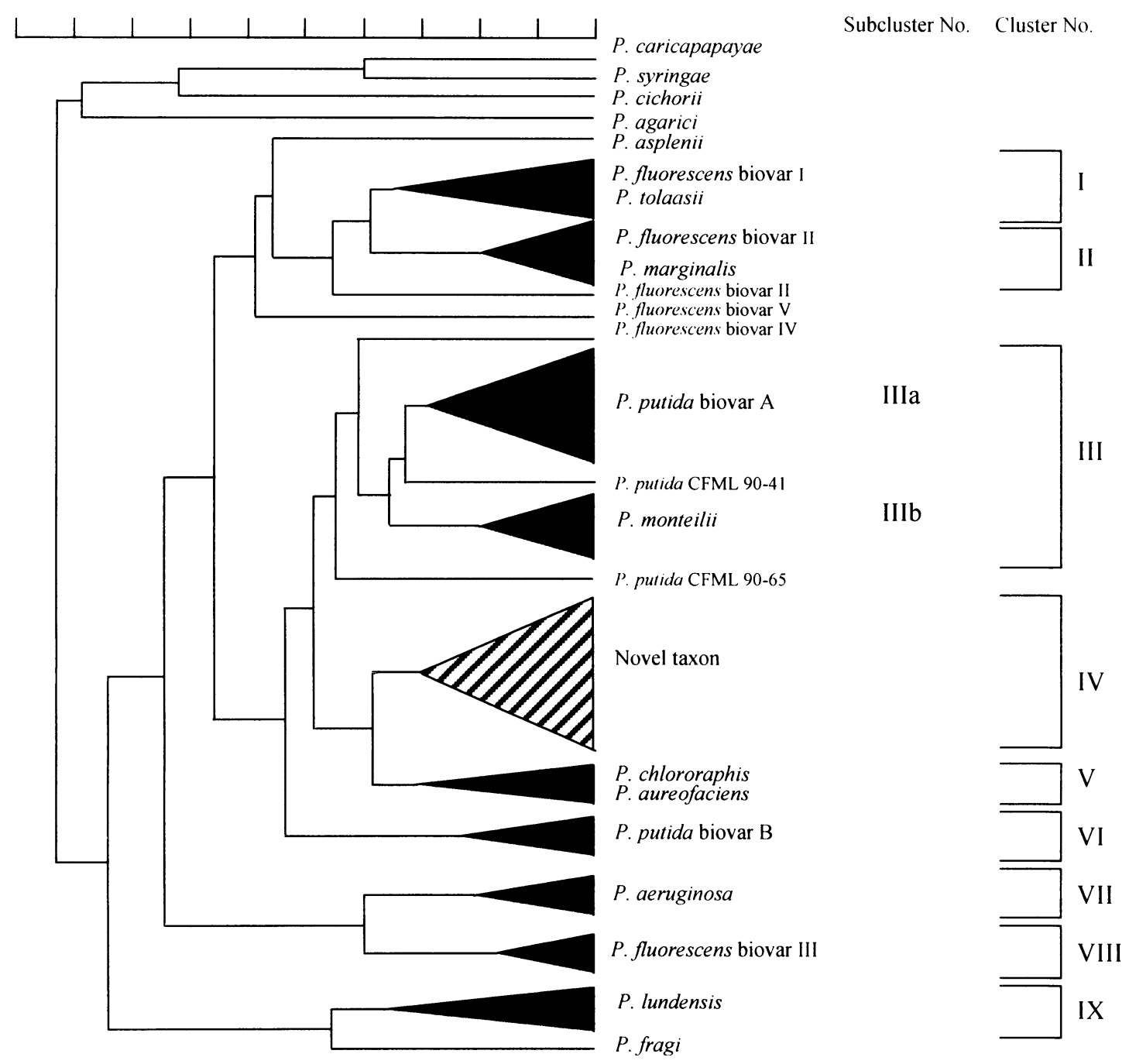

Fig. 1. Phenotypic dendrogram based on unweighted pair group average linkages. SD, Dice similarity index. The cut-off level between clusters is $62 \%$.

$c$ ), where ' $a$ ' is the number of positive resemblances, and ' $b$ ' and ' $c$ ' are the number of divergences. Groupings were made using the unweighted pair group method using arithmetic averages. The software used for the Dice coefficient and groupings determination was HIERAR (Université des Sciences et Technologies, Lille, France).

Isolation and purification of genomic DNA. Cells were grown on Mueller-Hinton agar plates at $30^{\circ} \mathrm{C}$, then harvested and washed in $10 \mathrm{mM}$ Tris buffer, $\mathrm{pH} 8$ containing $1 \mathrm{mM}$ EDTA and resuspended in the same buffer. Genomic DNA was extracted and purified by alkali lysis with SDS according to the method described by Beji et al. (1987).

DNA-DNA hybridization and thermal stability of reassociated DNAs. The relatedness of strains was determined by DNADNA hybridization as described by Grimont et al. (1980). DNA from strain CFML $90-83^{\mathrm{T}}$ (cluster IV, proposed below as the type strain of $P$. mosselii sp. nov.) was labelled in vitro with ${ }^{3} \mathrm{H}$-cytosine by nick-translation according to the manufacturer's instructions (Amersham). DNA hybridization reactions were done using the $\mathrm{S} 1$ nuclease/trichloroacetic acid method at $60{ }^{\circ} \mathrm{C}$ (Crosa et al., 1973; Grimont et al., 1980). The temperature at which $50 \%$ reassociated DNA was hydrolysed by nuclease $\mathrm{S} 1\left(T_{\mathrm{m}}\right)$ was determined using the method of Crosa et al. (1973). $\Delta T_{\mathrm{m}}$ is the difference between $T_{\mathrm{m}}$ of the heteroduplex and $T_{\mathrm{m}}$ of the homoduplex.

DNA base composition. The $\mathrm{G}+\mathrm{C}$ content of genomic DNA was calculated from the thermal denaturation curve using the equation of De Ley (1970). Escherichia coli ATCC $11775^{\mathrm{T}}$ DNA was used as the reference $(\mathrm{G}+\mathrm{C}$ content, $51 \mathrm{~mol} \%$ ).

Characterization of pyoverdines by isoelectrofocusing. Bacterial strains were grown for $40 \mathrm{~h}$ at $25^{\circ} \mathrm{C}$ with shaking (200 r.p.m.) in CAA medium [CAA medium contained $\left(\mathrm{g} \mathrm{l}^{-1}\right)$ : Casamino acids (Difco), 5; $\quad \mathrm{HK}_{2} \mathrm{PO}_{4}, \quad 1 \cdot 2$; 
Table 2. Features differentiating P. mosselii CFML $90-83^{\top}\left(=\right.$ ATCC BAA- $99^{\top}=$ CIP $\left.105259^{\top}\right)$ and closely related fluorescent species and biovars of the genus Pseudomonas

Strains: 1, P. mosselii; 2, P. monteilii; 3, P. fluorescens biovar I; 4, P. fluorescens biovar II; 5, P. fluorescens biovar III; 6 , P. fluorescens biovar IV; 7, P. fluorescens biovar V; 8, P. chlororaphis; 9, P. putida biovar A; 10, P. putida biovar B; 11, P. veronii; 12 , P. rhodesiae; 13, P. libanensis; 14, 'P. orientalis'; 15 , ' $P$. cedrella'.,$- 90 \%$ or more of the strains are negative;,$+ 90 \%$ or more of the strains are positive; $\mathrm{d}, 11-89 \%$ of the strains are positive; ND, not determined.

\begin{tabular}{|c|c|c|c|c|c|c|c|c|c|c|c|c|c|c|c|}
\hline Characteristic & 1 & 2 & 3 & 4 & 5 & 6 & 7 & 8 & 9 & 10 & 11 & 12 & 13 & 14 & 15 \\
\hline Pyocyanin production & - & - & - & - & - & - & - & - & - & - & - & - & - & - & - \\
\hline Denitrification & - & - & - & + & + & + & - & + & - & - & + & - & - & - & $\mathrm{d}$ \\
\hline Growth at $4{ }^{\circ} \mathrm{C}$ & - & - & + & + & + & + & $\mathrm{d}$ & + & $\mathrm{d}$ & + & + & + & + & + & + \\
\hline Growth at $41^{\circ} \mathrm{C}$ & - & - & - & - & - & - & - & - & - & - & - & - & - & - & - \\
\hline Lecithinase & $\mathrm{d}$ & - & + & $d$ & + & + & $\mathrm{d}$ & $\mathrm{d}$ & - & - & - & + & + & $\mathrm{d}$ & - \\
\hline Gelatinase & d & - & + & + & + & + & + & + & - & - & $\mathrm{d}$ & - & - & - & - \\
\hline \multicolumn{16}{|l|}{ Assimilation of: } \\
\hline Ribose & + & + & + & + & $\mathrm{d}$ & + & $\mathrm{d}$ & + & d & $\mathrm{d}$ & + & + & + & + & + \\
\hline D-Xylose & - & - & + & d & $\mathrm{d}$ & $\mathrm{d}$ & $\mathrm{d}$ & - & $\mathrm{d}$ & $\mathrm{d}$ & + & + & + & + & + \\
\hline$\alpha$-L-Rhamnose & $\mathrm{d}$ & - & - & $\mathrm{d}$ & $\mathrm{d}$ & - & $\mathrm{d}$ & - & - & - & - & - & $\mathrm{d}$ & $\mathrm{d}$ & $\mathrm{d}$ \\
\hline D-Mannose & + & - & + & + & + & + & $\mathrm{d}$ & + & $\mathrm{d}$ & $\mathrm{d}$ & + & + & + & + & + \\
\hline D-Mannitol & $\mathrm{d}$ & - & + & + & $\mathrm{d}$ & + & $\mathrm{d}$ & + & $\mathrm{d}$ & $\mathrm{d}$ & ND & ND & + & + & + \\
\hline D-Trehalose & $\mathrm{d}$ & - & + & + & $\mathrm{d}$ & + & $\mathrm{d}$ & + & - & - & $\mathrm{d}$ & + & d & + & + \\
\hline 2-Keto-D-gluconate & + & + & + & + & + & $\mathrm{d}$ & + & + & d & + & + & + & + & + & + \\
\hline Mucate & - & - & + & + & d & + & + & + & $\mathrm{d}$ & + & d & + & + & + & + \\
\hline Malonate & - & $\mathrm{d}$ & + & + & $\mathrm{d}$ & + & $\mathrm{d}$ & + & $\mathrm{d}$ & + & + & + & + & + & + \\
\hline D-Tartrate & - & - & - & $\mathrm{d}$ & - & - & $\mathrm{d}$ & - & $\mathrm{d}$ & $\mathrm{d}$ & - & - & - & - & $\mathrm{d}$ \\
\hline meso-Tartrate & + & - & - & - & $\mathrm{d}$ & - & d & - & d & - & - & - & $\mathrm{d}$ & - & - \\
\hline Erythritol & - & - & $\mathrm{d}$ & $\mathrm{d}$ & + & - & $\mathrm{d}$ & - & - & - & + & - & + & - & + \\
\hline D-Sorbitol & $\mathrm{d}$ & - & + & + & $\mathrm{d}$ & + & $\mathrm{d}$ & - & - & $\mathrm{d}$ & + & + & + & + & + \\
\hline myo-Inositol & - & + & d & + & $\mathrm{d}$ & + & $\mathrm{d}$ & + & - & - & + & + & + & + & + \\
\hline Adonitol & - & - & + & - & $\mathrm{d}$ & - & d & - & - & - & - & - & + & + & + \\
\hline Benzoate & - & + & d & $\mathrm{d}$ & $\mathrm{d}$ & + & $\mathrm{d}$ & $\mathrm{ND}$ & $\mathrm{d}$ & + & + & - & - & - & - \\
\hline$\alpha$-Aminobutyrate & + & + & - & - & - & - & - & - & - & $\mathrm{d}$ & + & + & + & + & + \\
\hline L-Histidine & + & + & + & $\mathrm{d}$ & + & + & $\mathrm{d}$ & + & + & + & $\mathrm{d}$ & + & - & - & - \\
\hline L-Tryptophan & - & - & + & d & d & - & $\mathrm{d}$ & + & - & + & + & - & - & - & - \\
\hline Histamine & + & d & $\mathrm{d}$ & - & $\mathrm{d}$ & - & $\mathrm{d}$ & d & $\mathrm{d}$ & + & - & - & - & - & - \\
\hline Tryptamine & - & - & - & $\mathrm{d}$ & $\mathrm{d}$ & - & - & - & $\mathrm{d}$ & + & - & - & - & - & _- \\
\hline Trigonelline & - & $\mathrm{d}$ & d & $\mathrm{d}$ & $\mathrm{d}$ & - & $\mathrm{d}$ & - & $\mathrm{d}$ & + & + & - & - & + & + \\
\hline
\end{tabular}

$\left.\mathrm{MgSO}_{4} .7 \mathrm{H}_{2} \mathrm{O}, 0 \cdot 25\right]$ dispensed as $7.5 \mathrm{ml}$ per $18 \times 180 \mathrm{~mm}$ capped test-tube and the pyoverdine-containing growth supernatant was subjected to isoelectrophoresis according to Koedam et al. (1994). The Bio-Rad model 111 mini isoelectrofocusing (IEF) cell apparatus was used under electrophoresis conditions as recommended by the manufacturer. A polyacrylamide gel (5\%) containing ampholines (BioLyte $3 / 10$; Bio-Rad) was prepared according to the manufacturer's recommendations and loaded with $1 \mu 1$ samples of 20-fold concentrated CAA growth supernatants. Supernatants were concentrated by lyophilization of $400 \mu 1$ growth supernatant, the residue being dissolved in $20 \mu \mathrm{l}$ double-distilled water. Pyoverdine bands were visualized under UV light and analysed for their corresponding isoelectric $\mathrm{pH}$ values $\left(\mathrm{pH}_{\mathrm{i}}\right)$ as previously described (Meyer et al., 1997).

16S rRNA gene sequence determination. The almost complete 16S rRNA gene sequence was determined for strain CFML $90-83^{\mathrm{T}}$ by direct PCR sequencing. DNA was amplified using the 16S rRNA universal primers pA (5'-
AGAGTTTGATCCTGGCTCAG-3') and pH (5'-AAGGAGGTGATCCAGCCGCA-3'), which are complementary to $E$. coli $16 \mathrm{~S}$ rRNA positions 8-27 and 1544-1525, respectively (Brosius et al., 1978; Edwards et al., 1989; Lane, 1991). PCR amplification was performed in a model 480 DNA thermal cycler (Perkin-Elmer) using a PCR mixture (final vol. $100 \mu \mathrm{l}$ ) containing each of the four dNTP at a concentration of $200 \mu \mathrm{M}$, primers $\mathrm{pA}$ and $\mathrm{pH}$ at a concentration of $1 \mathrm{mM}$ each, $1 \mu \mathrm{g}$ target DNA and $2.5 \mathrm{U}$ Taq DNA polymerase. The sequence of the PCR-amplified $16 \mathrm{~S}$ rRNA gene was determined directly, using an Applied Biosystems 377 automated DNA sequencer according to the protocols specified by the manufacturer and the following primers: $\mathrm{pA}$ and $\mathrm{pH}$ (used for amplification); primer 59-83 (5'-CTTATTCTGTCGGTAACGTC-3'); primer 21-83 (5'GGGCTCAACCTGGGAACTGC- $3^{\prime}$ ); primer 15-83 (5'TCCACCGCTTGTGCGGGCCC-3'); and primer 35-83 (5'-AGTTACCAGCCACGTCATGG-3'). The latter four primers covered the sequence at the following positions: 493-474, 608-627, 939-920 and 1116-1135, respectively [E. coli numbering (Brosius et al., 1978)]. 
Table 3. Levels of DNA relatedness of $P$. mosselii to different type and collection strains of the genus Pseudomonas

\begin{tabular}{|c|c|c|}
\hline \multirow[t]{2}{*}{ Source of unlabelled DNA* } & \multicolumn{2}{|c|}{ Labelled DNA from strain CFML $90-83^{\mathrm{T}}$} \\
\hline & $\operatorname{RBR}(\%) \dagger$ & $\Delta T_{\mathrm{m}}\left({ }^{\circ} \mathrm{C}\right)$ \\
\hline \multicolumn{3}{|l|}{ Cluster IV } \\
\hline CFML 90-83 & 100 & \\
\hline CFML 90-74 & 88 & \\
\hline CFML $90-78$ & 84 & \\
\hline CFML 90-70 & 81 & \\
\hline CFML $90-80$ & 80 & \\
\hline CFML 90-82 & 79 & 2 \\
\hline CFML $90-75$ & 77 & 4 \\
\hline CFML 90-71 & 75 & 1 \\
\hline CFML 90-77 & 74 & 4 \\
\hline CFML $90-73$ & 73 & 4 \\
\hline CFML 90-79 & 73 & 3 \\
\hline CFML 90-76 & 72 & 2 \\
\hline \multicolumn{3}{|l|}{ Cluster II } \\
\hline CFML 90-132 & 19 & \\
\hline \multicolumn{3}{|l|}{ Subcluster IIIa } \\
\hline CFML 90-42 & 18 & \\
\hline CFML 90-46 & 22 & \\
\hline CFML 90-47 & 26 & \\
\hline CFML 90-49 & 19 & \\
\hline CFML $90-52$ & 25 & \\
\hline CFML 90-39 & 10 & \\
\hline CFML 90-40 & 29 & \\
\hline \multicolumn{3}{|l|}{$\mathrm{NC}$} \\
\hline CFML 90-41 & 26 & \\
\hline CFML 90-65 & 41 & 8 \\
\hline P. putida biovar A ATCC $12633^{\mathrm{T}}$ & 40 & 9 \\
\hline P. putida biovar B CCUG 1317 & 15 & \\
\hline P. putida biovar B ATCC 17430 & 20 & \\
\hline P. putida biovar B ATCC 17484 & 22 & \\
\hline P. monteilii CIP $104833^{\mathrm{T}}$ & 49 & 10 \\
\hline P. aeruginosa ATCC $10145^{\mathrm{T}}$ & 20 & \\
\hline P. aeruginosa ATCC 27853 & 19 & \\
\hline P. aeruginosa ATCC 15692 & 13 & \\
\hline P. fluorescens biovar I ATCC $13525^{\mathrm{T}}$ & 33 & \\
\hline P. fluorescens biovar I ATCC 17563 & 20 & \\
\hline P. fluorescens biovar II ATCC 17816 & 29 & \\
\hline P. fluorescens biovar II ATCC 17815 & 22 & \\
\hline P. fluorescens biovar II ATCC 17482 & 18 & \\
\hline P. fluorescens biovar II DSM 50106 & 26 & \\
\hline P. fluorescens biovar III ATCC 17559 & 15 & \\
\hline P. fluorescens biovar III ATCC 17400 & 16 & \\
\hline P. fluorescens biovar III ATCC 17571 & 15 & \\
\hline P. fluorescens biovar IV DSM 50415 & 16 & \\
\hline P. fluorescens biovar IV ATCC 12983 & 13 & \\
\hline P. fluorescens biovar V ATCC 14150 & 25 & \\
\hline P. fluorescens biovar V ATCC 17518 & 34 & \\
\hline P. fluorescens biovar V ATCC 15916 & 16 & \\
\hline P. fluorescens biovar V ATCC 17386 & 15 & \\
\hline P. fluorescens biovar V ATCC 17573 & 18 & \\
\hline P. fluorescens biovar V DSM 50148 & 16 & \\
\hline P. marginalis ATCC $10844^{\mathrm{T}}$ & 19 & \\
\hline P. marginalis DSM 50275 & 22 & \\
\hline
\end{tabular}


Table 3 (cont.)

\begin{tabular}{|c|c|c|}
\hline \multirow[t]{2}{*}{ Source of unlabelled DNA* } & \multicolumn{2}{|c|}{ Labelled DNA from strain CFML $90-83^{\mathrm{T}}$} \\
\hline & $\operatorname{RBR}(\%) \dagger$ & $\Delta T_{\mathrm{m}}\left({ }^{\circ} \mathrm{C}\right)$ \\
\hline P. marginalis DSM 50276 & 25 & \\
\hline P. libanensis CIP $105460^{\mathrm{T}}$ & 15 & \\
\hline 'P. cedrella' CIP $105541^{\mathrm{T}}$ & 9 & \\
\hline 'P. orientalis' CIP $105540^{\mathrm{T}}$ & 12 & \\
\hline P. chlororaphis DSM 50083 & 16 & \\
\hline P. chlororaphis ATCC 9447 & 33 & \\
\hline P. chlororaphis ATCC 17414 & 17 & \\
\hline P. aureofaciens ATCC $13985^{\mathrm{T}}$ & 31 & \\
\hline P. aureofaciens ATCC 17415 & 23 & \\
\hline P. veronii CIP $104663^{\mathrm{T}}$ & 32 & \\
\hline P. rhodesiae CIP $104664^{\mathrm{T}}$ & 36 & \\
\hline P. synxantha CIP $5922^{\mathrm{T}}$ & 27 & \\
\hline P. mucidolens CIP $103298^{\mathrm{T}}$ & 30 & \\
\hline P. lundensis CCM 573 & 14 & \\
\hline P. lundensis CCUG 18785 & 10 & \\
\hline P. syringae ATCC $19310^{\mathrm{T}}$ & 16 & \\
\hline P. savastanoi CFBP $1670^{\mathrm{T}}$ & 9 & \\
\hline P. savastanoi CFBP 2088 & 13 & \\
\hline P. savastanoi CFBP 1838 & 11 & \\
\hline P. viridiflava ATCC $13223^{\mathrm{T}}$ & 9 & \\
\hline P. cichorii DSM $50259^{\mathrm{T}}$ & 11 & \\
\hline$P$. agaricii ATCC $25941^{\mathrm{T}}$ & 10 & \\
\hline P. asplenii ATCC $23835^{\mathrm{T}}$ & 10 & \\
\hline P. caricapapayae NCPPB $1873^{\mathrm{T}}$ & 7 & \\
\hline P. tolaasii NCPPB $2129^{\mathrm{T}}$ & 24 & \\
\hline P. tolaasii NCPPB 1616 & 20 & \\
\hline P. stutzeri ATCC $17588^{\mathrm{T}}$ & 7 & \\
\hline P. stutzeri ATCC 17591 & 9 & \\
\hline P. stutzeri ATCC 17587 & 10 & \\
\hline P. stutzeri ATCC 17686 & 7 & \\
\hline P. mendocina ATCC $25411^{\mathrm{T}}$ & 7 & \\
\hline P. mendocina ATCC 25412 & 8 & \\
\hline$P$. alcaligenes ATCC $14909^{\mathrm{T}}$ & 11 & \\
\hline P. pseudoalcaligenes ATCC $17440^{\mathrm{T}}$ & 8 & \\
\hline P. pseudoalcaligenes ATCC 12815 & 9 & \\
\hline P. fragi CCUG $1313^{\mathrm{T}}$ & 10 & \\
\hline P. fragi ATCC 27362 & 11 & \\
\hline P. flavescens NCPPB $3063^{\mathrm{T}}$ & 19 & \\
\hline P. flavescens CIP 104205 & 12 & \\
\hline P. fuscovaginae NCPPB $3085^{\mathrm{T}}$ & 9 & \\
\hline
\end{tabular}

* CFBP, Collection Franćaise de Bactéries Phytopathogènes, Station de Pathologie Végétale et Phytobactériologie, Institut National de la Recherche Agronomique, Beaucouzé, France. For definitions of other abbreviations, see footnote to Table 1.

$\dagger$ RBR, Relative binding ratio.

Analysis of sequence data. The $16 \mathrm{~S}$ rRNA gene sequence determined and the sequences of other pseudomonad reference strains obtained from the EMBL database were aligned and analysed using the CLUSTAL x program (Thompson et al., 1997). Nucleotide substitution rates ( $K_{\text {nuc }}$ values) were calculated (Kimura, 1980) and a phylogenetic tree was constructed by the neighbour-joining method of Saitou \& Nei (1987). An evaluation of the tree was carried out using the bootstrap method (Felsenstein, 1985). A total of 1000 bootstrapped trees was generated. Calculations of levels of sequence similarity were based on data for $1322 \mathrm{nt}$.

\section{RESULTS}

\section{Numerical analysis of phenotypic characters}

Fifty of the 280 characters determined for all the strains of this study were either universally positive or 
negative and were excluded from the analysis. At a similarity level of $62 \%$, the numerical analysis delineated nine main clusters, (Fig. 1; Table 1). Cluster III could be further divided at a higher level of similarity into two subclusters IIIa and IIIb. Ten strains formed single strain clusters: Pseudomonas caricapapayae NCPPB $1873^{\mathrm{T}}, P$. syringae ATCC $19310^{\mathrm{T}}$, Pseudomonas fragi CCUG $1313^{\mathrm{T}}$, P. cichorii DSM 50259 ${ }^{\mathrm{T}}$, P. agarici ATCC $25941^{\mathrm{T}}$, Pseudomonas asplenii ATCC $23835^{\mathrm{T}}$, P. fluorescens biovar V DSM 50148, P. fluorescens biovar II ATCC 17815, P. putida CFML 90-65 and $P$. fluorescens biovar IV DSM 50415. Phenotypic characteristics of the type strains of the reference species used in this study were in good agreement with published data (Barrett et al., 1986;
Coroler et al., 1996; Dabboussi et al., 1998; Elomari et al., 1996; Grimont et al., 1996; Palleroni, 1984; Stanier et al., 1966): cluster II $(n=5)$ included P. marginalis ATCC $10844^{\mathrm{T}}$ and two $P$. marginalis strains of plant origin and two $P$. fluorescens strains; subcluster IIIa $(n=8)$ contained the type strain $P$. putida biovar A ATCC $12633^{\mathrm{T}}$ and seven $P$. putida strains isolated from clinical specimens; subcluster IIIb $(n=5)$ included the type strain P. monteilii CIP $104883^{\mathrm{T}}$ and four strains of the same species isolated from human clinical specimens; cluster VII $(n=2)$ comprised the type strain of $P$. aeruginosa ATCC $10145^{\mathrm{T}}$ and a strain of the same species from clinical origin; cluster IX $(n=2)$ contained the type strain of Pseudomonas lundensis CCM $573^{\mathrm{T}}$ and the strain P. lundensis CCUG 18758, both

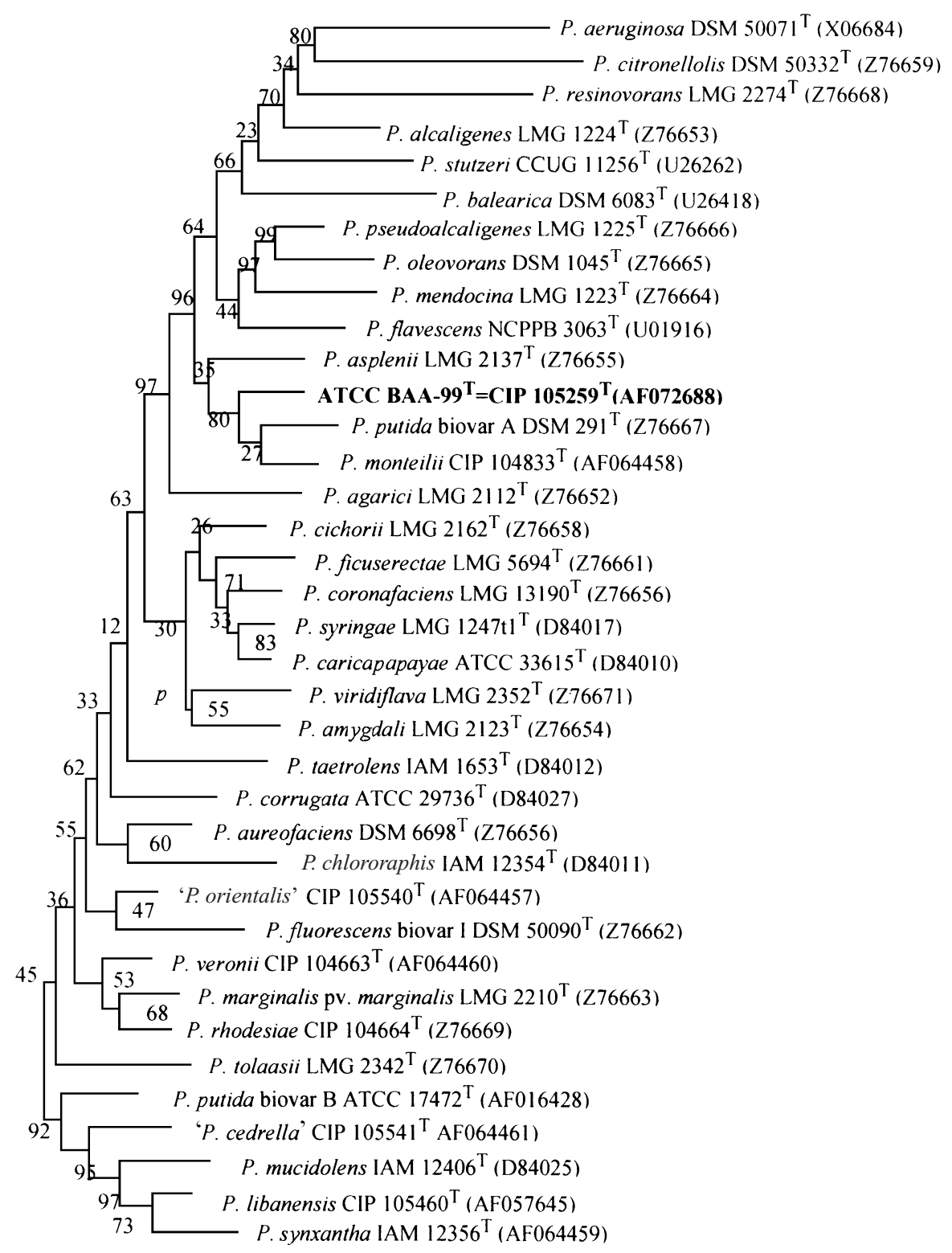

Fig. 2. Unrooted tree constructed using the neighbour-joining method showing the phylogenetic relationships of P. mosselii (= ATCC BAA- $99^{\top}=$ CIP $\left.105259^{\top}\right)$ and other species of the genus Pseudomonas sensu stricto. Numbers indicate the percentage occurrence of the branch in bootstrapped trees. 
isolated from beef. The following clusters included two type strains of the reference species: cluster $\mathrm{V}(n=2)$ grouped the type strains Pseudomonas aureofaciens ATCC $13985^{\mathrm{T}}$ and Pseudomonas chlororaphis DSM $50083^{\mathrm{T}}$, which have been shown to be members of the same genospecies (Champion et al., 1980); cluster I $(n=4)$ included two type strains $P$. tolaasii NCPPB $2192^{\mathrm{T}}$ and $P$. fluorescens biovar I ATCC $13525^{\mathrm{T}}$, associated with $P$. tolaasii strain NCPPB 1616 and P. fluorescens biovar I strain ATCC 17563.

The 22 strains of our collection isolated from clinical specimens were distributed as follows: 1 strain ( $P$. fluorescens) in cluster II, 8 strains $(P$. putida) in cluster III, 12 strains (1 P. putida, 2 Pseudomonas sp., 9 P. fluorescens) in cluster IV and 1 strain (P. putida) remained unclustered. This last cluster (cluster IV) did not include any type strain or strains from any other collection (Table 1). The phenotypic data of the 12 strains of cluster IV (proposed below as P. mosselii sp. nov.) are compared in Table 2 with those of other species, among them the non-phytopathogenic members of section I pseudomonads (Palleroni et al., 1973): $P$. aeruginosa, $P$. fluorescens biovars $\mathrm{I}-\mathrm{V}, P$. putida biovar A and $\mathrm{B}$ and $P$. chlororaphis and the newly described species $P$. veronii (Elomari et al., 1996), $P$. rhodesiae (Coroler et al., 1996), P. monteilii (Elomari et al., 1997), 'P. cedrella', 'P. orientalis' (Dabboussi et al., 1999a) and P. libanensis (Dabboussi et al., 1999b).

\section{DNA-DNA hybridization and thermal stability}

Results of DNA-DNA hybridizations obtained with labelled DNA of strain CFML $90-83^{\mathrm{T}}$ are shown in Table 3. Hybridization values between strains within cluster IV were $72-100 \%$ and the $\Delta T_{\mathrm{m}}$ value was $1-4{ }^{\circ} \mathrm{C}$. Hybridization experiments were also performed between strain CFML $90-83^{\mathrm{T}}$ and the 10 clinical isolates belonging to the other clusters identified by phenotypic analysis. All values were in the range $10-41 \%$. The highest DNA-DNA hybridization value was obtained with $P$. monteilii CIP $104833^{\mathrm{T}}$ $(49 \%)$, with a $\Delta T_{\mathrm{m}}$ of $10^{\circ} \mathrm{C}$. Table 3 also shows the level of reassociation between strain CFML 90-83 and all of the reference strains of the genus Pseudomonas used in this study (67 strains). All values were less than $49 \%$, with $\Delta T_{\mathrm{m}}$ values of $8-10{ }^{\circ} \mathrm{C}$.

\section{DNA base composition}

The $\mathrm{G}+\mathrm{C}$ contents of strains CFML $90-83^{\mathrm{T}}$, CFML 90-74, CFML 90-70 and CFML 90-80 were 63, 62, 61 and $62 \mathrm{~mol} \%$, respectively.

\section{S rDNA sequence analysis}

The sequence of $1322 \mathrm{nt}$ of the 16S rDNA gene of strain CFML $90-83^{\mathrm{T}}$ was aligned to databaseavailable sequences of other species of the genus Pseudomonas sensu stricto (Kersters et al., 1996), including six newly described species: $P$. veronii (Elomari et al., 1996), P. rhodesiae (Coroler et al., 1996),

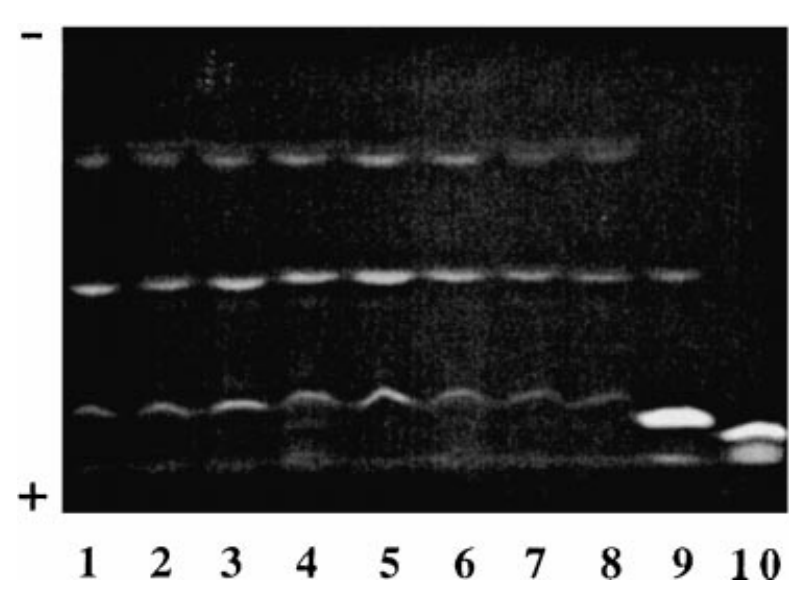

Fig. 3. IEF of the pyoverdines produced by $P$. mosselii strains CFML 90-71, 90-73, 90-74, 90-77, 90-78, 90-80, 90-82, 90-83 ${ }^{\top}$ (lanes 1-8, respectively), P. monteilii CFML 90-54 (lane 9) and P. putida ATCC $12633^{\top}$ (lane 10).

P. monteilii (Elomari et al., 1997), P. libanensis (Dabboussi et al., 1999b), ' $P$. cedrella' and $P$. orientalis (Dabboussi et al., 1999a). The tree constructed by the neighbour-joining method (Saitou \& Nei, 1987) and showing phylogenetic relationships of strain CFML $90-83^{\mathrm{T}}$ with 36 type strains is illustrated in Fig. 2. Its closest relatives are $P$. monteilii, $P$. putida biovar A and $P$. asplenii. Levels of nucleotide similarities for the 16S rDNA sequence of strain CFML $90-83^{\mathrm{T}}$ and other Pseudomonas species were greater than $95.3 \%$ (Pseudomonas resinovorans). Strain CFML $90-83^{\mathrm{T}}$ was most closely related, in terms of sequence similarity, to $P$. monteilii $(99 \cdot 4 \%$ ). Our $16 \mathrm{~S}$ rDNA sequence comparison confirmed that strain CFML $90-83^{\mathrm{T}}$ belongs to the genus Pseudomonas.

\section{Characterization of strains by pyoverdine typing}

The pyoverdines synthesized during growth under iron starvation conditions by isolates of phenotypic cluster IV all presented an identical IEF pattern (Fig. 3) for 8 different isolates. Three major pyoverdine bands, corresponding to different isoforms of an otherwise identical molecule (Budzikiewicz, 1997), were characterized by $\mathrm{pH}_{\mathrm{i}}$ values of $9 \cdot 0,7 \cdot 4$ and $5 \cdot 2$, respectively (from top to bottom in Fig. 3, lanes 1-8). Several supplementary minor bands were more or less visible, depending on the amount of pyoverdines accumulated by the strains during growth. None of the 37 strains analysed among the other fluorescent pseudomonad species listed in Table 3 displayed the same IEF profile, as illustrated for two strains, P. monteilii CFML 90-54 (Fig. 3, lane 9) and $P$. putida ATCC $12633^{\mathrm{T}}$ (Fig. 3, lane 10). Strain CFML 90-75, unique among isolates of cluster IV, revealed no pyoverdine production when grown under iron-deficient conditions and, thus, remained uncharacterized by the IEF method. Therefore, the strain was tested for pyoverdine-mediated iron incorporation (Meyer et al., 1997) and demonstrated an efficient capacity, identical to that of the 
Table 4. Variable characters within the 12 P. mosselii strains

+ , Positive; - , negative; C, $50 \%$ of strains positive. All type strain reactions were identical to those of the majority of $P$. mosselii strains, except for: gelatinase, Tween esterase, fibrinolysis, assimilation of L-threonine, ethanolamine, levulinate, adipate, 2 -ketoglutarate, L-tyrosine arylamidase, L-ornithine arylamidase and $N$-acetyl- $\beta$-D-glucosaminidase. All $P$. mosselii strains utilized the following substrates as carbon and energy sources: glycerol, ribose, D-glucose, D-fructose, $N$-acetyl-glucosamine, gluconate, 2-ketogluconate, D-alanine, L-alanine, L-leucine, L-isoleucine, L-valine, L-serine, L-phenylalanine, L-histidine, L-aspartate, L-glutamate, L-ornithine, L-lysine, L-citrulline, L-arginine, betaine, $\beta$-alanine, DL-4-amino-butyrate, DL-5-amino-valerate, sarcosine, diaminobutane, spermine, histamine, acetate, propionate, butyrate, isobutyrate, n-valerate, isovalerate, n-caproate, heptanoate, caprylate, pelargonate, caprate, glutarate, DL-lactate, DL-glycerate, DL-3-hydroxy-butyrate, D-malate, meso-tartrate, pyruvate, aconitate, citrate, phenyl-acetate, $p$-hydroxy-benzoate, L-proline, succinate, fumarate and L-malate. No strain used the following substrates as carbon and energy sources: erythritol, D-arabinose, L-arabinose, D-xylose, adonitol, methyl $\beta$-xyloside, L-sorbose, dulcitol, inositol, methyl $\alpha$-D-glucoside, amygdalin, arbutin, glycogen, $\beta$-gentiobiose, D-lyxose, L-arabitol, 5-ketogluconate, L-norleucine, DL-norvaline, DL-2-aminobutyrate, L-tryptophan, DL-kynurenine, creatine, DL-3-amino-butyrate, DL-2-aminobenzoate, acetamide, benzylamine, tryptamine, malonate, maleate, pimelate, suberate, azelate, sebacate, glycolate, D-tartrate, L-tartrate, citraconate, itaconate, mesaconate, benzoate, $o$-hydroxy-benzoate, $m$-hydroxy-benzoate, D-mandelate, L-mandelate, phthalate, tere-phthalate, L-xylose, methyl $\alpha$-D-mannoside, salicin, lactose, D-melebiose, inulin, D-tagatose, D-fucose, L-cysteine, D-tryptophan, DL-3-amino-benzoate, DL-4-amino-benzoate, ethylamine, oxalate, iso-phthalate. All strains possess the following enzyme activities: L-hydroxyproline arylamidase, L-histidine arylamidase, glycine arylamidase, L-arginine arylamidase, $\gamma$-glutamyltransferase, methionine arylamidase, glycyl-glycine arylamidase, glycyl-phenylalanine arylamidase, leucyl-glycine arylamidase, L-glutamine arylamidase, L-proline arylamidase, L-serine arylamidase, $\beta$-alanine arylamidase, glycyl-L-alanine arylamidase, glycyl-L-tryptophan arylamidase, L-leucyl-L-alanine arylamidase, L-seryl-L-methionine arylamidase, L-lysine arylamidase, L-alanine arylamidase, and esterases-C4, -C6, -C8, -C9, -C10 and -C19. No strains possess the following enzyme activities: pyrrolidone arylamidase, L-aspartate arylamidase, $\mathrm{N}$-CBZ-glycyl-arginine arylamidase, L-alanyl-L-phenylalanyl-Lproline arylamidase, L-alanyl-L-phenylalanyl-L-prolyl-L-alanine arylamidase, $\alpha$-L-aspartyl-L-alanine arylamidase, $\alpha$-L-aspartylL-arginine arylamidase, $N$-benzoyl-leucine arylamidase, $S$-benzoyl-cysteine arylamidase, $N$-CBZ-arginine-4-methoxy arylamidase, L-leucyl-L-leucyl-L-valyl-L-tyrosyl-L-serine arylamidase, $N$-benzoyl-L-alanyl-4-methoxy arylamidase, $N$-acetyl-glycyl-L-lysine arylamidase, $\alpha$-D-galactosidase, $\beta$-D-galactosidase, phospho- $\beta$-D-galactosidase, $\alpha$-L-arabinosidase, $\beta$-D-galacturonohydrolase, $\beta$-D-glucuronidase, $\beta$-maltosidase, $N$-acetyl- $\alpha$-D-glucosaminidase, $\alpha$-D-fucosidase, $\beta$-L-fucosidase, $\beta$-D-lactosidase, $\alpha$-D-mannosidase, $\beta$-D-mannosidase, $\alpha$-D-xylosidase, $\beta$-D-xylosidase, $\alpha$-D-glucosidase, $\beta$-D-glucosidase, $\alpha$-maltosidase, $\alpha$-L-fucosidase, esterases-C16, L-lysyl-L-serine-4-methoxy arylamidase.

\begin{tabular}{|c|c|c|}
\hline Character & P. mosselii strains $(n=12) *$ & $\begin{array}{c}\text { Type strain CFML } \\
9^{90-83^{T}}\end{array}$ \\
\hline \multicolumn{3}{|l|}{ Conventional tests: } \\
\hline Gelatinase & $+(11)$ & - \\
\hline Tween esterase & $\mathrm{C}(6)$ & - \\
\hline Lecithinase, haemolysis & $-(8)$ & - \\
\hline Fibrinolysis & $+(8)$ & - \\
\hline \multicolumn{3}{|l|}{ Carbon sources: } \\
\hline Galactose, rhamnose, maltose, sucrose, xylitol, glucosamine & $-(10)$ & - \\
\hline Butylamine, amylamine & $+(11)$ & + \\
\hline Mannitol, D-arabitol, L-tyrosine & $+(9)$ & + \\
\hline Sorbitol, aesculin, D-melezitose, D-turanose, L-fucose, D-raffinose & $-(10)$ & - \\
\hline D-Cellobiose & $-(8)$ & - \\
\hline Glycine, L-methionine & $-(7)$ & - \\
\hline Starch & $-(11)$ & - \\
\hline L-Threonine & $+(9)$ & - \\
\hline Ethanolamine, levulinate & $+(11)$ & - \\
\hline Adipate & $-(11)$ & + \\
\hline \multicolumn{3}{|l|}{ Enzymic tests: } \\
\hline L-Tyrosine arylamidase & $-(7)$ & + \\
\hline L-Phenylalanine arylamidase, L-tryptophan arylamidase & $+(10)$ & + \\
\hline Glycyl-proline arylamidase & $-(7)$ & - \\
\hline $\begin{array}{l}\text { L-Seryl-tyrosine arylamidase, L-alanyl-L-arginine arylamidase, } \\
\text { glycyl-L-arginine arylamidase, L-phenylalanyl-L-arginine arylamidase, } \\
\text { L-phenylalanyl-L-proline arylamidase, L-threonine arylamidase, } \\
\text { L-arginyl-L-arginine arylamidase, L-histidyl-L-leucyl-L-histidine arylamidase }\end{array}$ & $-(10)$ & - \\
\hline $\begin{array}{l}\alpha \text {-L-Glutamate arylamidase, } \mathrm{L} \text {-isoleucine arylamidase, } \\
\alpha \text {-L-glutamyl-L-histidine arylamidase, L-histidyl-L-serine arylamidase, } \\
\text { L-phenylalanyl-L-prolyl-L-alanine arylamidase }\end{array}$ & $-(11)$ & - \\
\hline
\end{tabular}




\begin{tabular}{|c|c|c|}
\hline Character & P. mosselii strains $(n=12)^{*}$ & $\begin{array}{c}\text { Type strain CFML } \\
{900-83^{T}}^{T}\end{array}$ \\
\hline L-Ornithine arylamidase, & $+(7)$ & - \\
\hline L-Lysyl-L-alanine arylamidase & $+(11)$ & + \\
\hline L-Lysyl-L-lysine arylamidase, L-valyl-L-tyrosyl-L-serine arylamidase & $-(9)$ & - \\
\hline L-Histidyl-L-phenylalanine arylamidase & $-(8)$ & - \\
\hline$N$-Acetyl- $\beta$-D-glucosaminidase & $+(10)$ & - \\
\hline Esterases-C5, -C12, -C14 & $+(11)$ & + \\
\hline
\end{tabular}

* Numbers in parentheses are the number of strains with the recorded result.

other isolates of cluster IV, for incorporating iron liganded to the pyoverdine of strain CFML 90-83 (data not shown).

\section{DISCUSSION}

Twenty-two strains isolated from clinical specimens received as $P$. putida (10 strains), P. fluorescens (10 strains) and Pseudomonas sp. (2 strains) were studied by a polyphasic taxonomic approach, including $16 \mathrm{~S}$ rDNA phylogeny, numerical analysis, DNA-DNA hybridization and thermal stability of DNA-DNA hybrids, as well as by the recently described siderotyping methodology (Meyer et al., 1997). These strains, which phenotypically belong to the fluorescent pseudomonad group, were mainly grouped (19 strains) into two phenotypic clusters, IIIa and IV. Phenotypic cluster IIIa also included the $P$. putida biovar A type strain. Cluster IV contained 12 clinical isolates, but no type strains or strains from other collections. These results suggest that cluster IV isolates belong to the genus Pseudomonas sensu stricto. To further unravel the finer taxonomic position of the cluster IV isolates within this genus, DNA-DNA hybridizations were performed within this cluster and with the type and other representative strains of related groups or species. Cluster IV constituted a separate DNA hybridization group (72-100\% hybridization, $\Delta T_{\mathrm{m}}$ values less than $4{ }^{\circ} \mathrm{C}$ ) with only low levels of DNA hybridization with other species of the genus Pseudomonas sensu stricto, including the newly described species $P$. veronii, $P$. rhodesiae, $P$. monteilii, $P$. libanensis, ' $P$. cedrella' and ' $P$. orientalis'. Furthermore, the DNA-DNA hybridization values obtained between strain CFML $90-83^{\mathrm{T}}$ and all strains of cluster IIIa were low. The $\Delta T_{\mathrm{m}}$ values obtained for hybrids between strain CFML $90-83^{\mathrm{T}}$ and reference strains of the genus Pseudomonas were high $\left(9-10^{\circ} \mathrm{C}\right)$. At present, the species is the basic unit of bacterial taxonomy and is defined as a group of strains sharing $70 \%$ or greater DNA-DNA relatedness with a $\Delta T_{\mathrm{m}}$ value of $5^{\circ} \mathrm{C}$ or less. Both values have to be considered and phenotypic features also have to agree with this definition (Stackebrandt \& Goebel, 1994).

The mean DNA G $+\mathrm{C}$ content was $62 \mathrm{~mol} \%$ for the four strains studied (CFML 90-83 , CFML 90-74,
CFML 90-70 and CFML 90-80). This value is typical of the genus Pseudomonas sensu stricto (58-70 mol \% ; Palleroni, 1984). The derived 16S rRNA sequence of strain CFML $90-83^{\mathrm{T}}$ was aligned and compared with the sequences of other Pseudomonas species retrieved from the EMBL database. Strain CFML 90-83 ${ }^{\mathrm{T}}$ exhibited the lowest level of 16S rRNA sequence similarity with $P$. resinovorans $(95 \cdot 3 \%)$. The highest level of sequence relatedness was observed with $P$. monteilii CIP $104883^{\mathrm{T}}(99 \cdot 4 \%)$, but strains of cluster IV could be differentiated from $P$. monteilii by DNADNA hybridization and several phenotypic features such as assimilation of D-mannose, meso-tartrate, myoinositol and benzoate. Furthermore, the phylogenetic tree shows that the node of the $P$. mosselii/P. putida biovar A/P. monteilii grouping appeared with an occurrence of $80 \%$, which is considered to be high. In fact, molecular methods are essential for determining the precise taxonomic organization of the bacterial world. Comparisons of rRNA sequences of corresponding genes allow phylogenetic reconstruction (De Vos \& De Ley, 1983; Fox et al., 1980; Grimont \& Grimont, 1986; Palleroni et al., 1973). The taxonomic information thus obtained is invaluable above the species level and for species delineation; however, quantitative DNA-DNA hybridization presently remains the most straightforward method for describing a species (Wayne et al., 1987). The phylogenetic tree shows that strain CFML $90-83^{\mathrm{T}}$ falls within the genus Pseudomonas and specifically within the $P$. fluorescens intrageneric cluster as defined by Moore et al. (1996). The pyoverdine typing performed by IEF was also a powerful molecular method for discriminating the members of cluster IV from all other fluorescent Pseudomonas species so far analysed. An identical pyoverdine IEF pattern suggests production of a structurally identical pyoverdine that appeared to be specific to isolates of cluster IV. Initially developed for the differentiation of $P$. aeruginosa isolates (Meyer et al., 1997) and also successfully used recently for recognition of the novel species Pseudomonas brassicacearum and Pseudomonas thivervalensis (Achouak et al., 2000), siderotyping appears to be a promising new methodology for taxonomic purposes among the fluorescent Pseudomonas spp. Furthermore, pyoverdine-mediated iron uptake studies could replace 
pyoverdine IEF analysis for strains naturally deficient in pyoverdine production, as shown in the present study for P. mosselii CFML 90-75.

As a conclusion of the polyphasic study, a novel Pseudomonas species, $P$. mosselii sp. nov., is proposed for the 12 strains of cluster IV. Affiliation to the genus Pseudomonas is justified by the close phylogenetic relationships of strain CFML $90-83^{\mathrm{T}}$ to other strains representative of the genus. The low level of DNADNA relatedness to other Pseudomonas strains justifies the creation of $P$. mosselii as a novel species. P. mosselii strains are phenotypically and genotypically (DNADNA hybridization) homogeneous, with a clear and characteristic set of phenotypic features (Table 2 and Table 4) that allow identification to the species level. $P$. mosselii strains could be differentiated from related fluorescent members of the genus Pseudomonas by several phenotypic features (Table 2). Differentiation of $P$. mosselii and $P$. aeruginosa is based on pyocyanin production, denitrification, growth at $41^{\circ} \mathrm{C}$ and assimilation of D-mannose, malonate, meso-tartrate, benzoate and $\alpha$-aminobutyrate. $P$. fluorescens (all biovars) and $P$. putida biovar A could be generally differentiated from $P$. mosselii by the assimilation of $\alpha$-aminobutyrate. $P$. mosselii and $P$. putida biovar B differed phenotypically since all strains of $P$. putida biovar B assimilate mucate, malonate, benzoate, tryptamine and L-tryptophan, whereas strains of P. mosselii are unable to utilize these compounds.

Moreover, P. mosselii strains could be characterized by their unique pyoverdine IEF pattern. Investigations of a larger collection of bacteria is in progress to assess the use of this method for taxonomic purposes among the fluorescent Pseudomonas.

\section{Description of Pseudomonas mosselii sp. nov.}

Pseudomonas mosselii (mos.se'li.i. M.L. masc. gen. n. mosselii of Mossel, in honour of David A. A. Mossel, a Dutch microbiologist, for his contribution to medical and food microbiology).

Sources of the P. mosselii strains are shown in Table 1 . Gram-negative, motile by a single polar flagellum, asporogenous and rod-shaped. Cells produce a fluorescent pigment on King B medium, but do not produce phenazine pigments on King A medium. Colonies on nutrient agar are circular and non-pigmented. Temperature range for growth is $10-36{ }^{\circ} \mathrm{C}$; optimal growth occurs at $30{ }^{\circ} \mathrm{C}$. Growth occurs in the presence of 3 and $5 \% \mathrm{NaCl}$, but not in the presence of $7 \% \mathrm{NaCl}$. Able to grow on cetrimide. Non-haemolytic on blood agar. Does not reduce nitrate to nitrite. Negative for elastase, coagulase, chondroitinase, hyaluronidase and tetrathionate reductase. Arginine dihydrolase, catalase and cytochrome oxidase are produced. Lysine and ornithine are not decarboxylated. L-Tyrosine is hydrolysed, but not aesculin. Negative Voges-Proskauer reaction and tributyrin test. No action against DNA or RNA. Phenotypic characters which are either positive or negative for all the $P$. mosselii strains are listed in
Table 4. Variable characteristics of $12 P$. mosselii strains are shown in Table $4 . \mathrm{G}+\mathrm{C}$ content of the type strain is $63 \mathrm{~mol} \%$. All strains were isolated from clinical specimens, but the clinical significance of $P$. mosselii is not known. Type strain is CFML $90-83^{\mathrm{T}}$ $\left(=\right.$ ATCC BAA $-99^{\mathrm{T}}=$ CIP $\left.105259^{\mathrm{T}}\right)$.

\section{REFERENCES}

Achouak, W., Sutra, L., Heulin, T., Meyer, J.-M., Fromin, N., Degraeve, S., Christen, R. \& Gardan, L. (2000). Pseudomonas brassicacearum sp. nov. and Pseudomonas thivervalensis sp. nov., two root-associated bacteria isolated from Brassica napus and Arabidopsis thaliana. Int J Syst Evol Microbiol 50, 9-18.

Barrett, E. L., Solanes, R. E., Tang, J. S. \& Palleroni, N. J. (1986). Pseudomonas fluorescens biovar V: its resolution into distinct component groups and the relationship of these groups to other $P$. fluorescens biovars, to $P$. putida, and to psychrotrophic pseudomonads associated with food spoilage. J Gen Microbiol 132, 2709-2721.

Beji, A., Izard, D., Gavini, F., Leclerc, H., Leseine-Delstanche, M. \& Krembel, J. (1987). A rapid chemical procedure for isolation and purification of chromosomal DNA from Gram-negative bacilli. Anal Biochem 161, 18-23.

Blazevic, D. J., Koepcke, M. H. \& Matsen, J. M. (1973). Incidence and identification of Pseudomonas fluorescens and Pseudomonas putida in the clinical laboratory. Appl Microbiol 25, 107-110.

Bowman, J. P., Sly, L. I., Hayward, A. C., Spiegel, Y. \& Stackebrandt, E. (1993). Telluria mixta (Pseudomonas mixta Bowman, Sly, and Hayward 1988) gen. nov., comb. nov., and Telluria chitinolytica sp. nov., soil-dwelling organisms which actively degrade polysaccharides. Int J Syst Bacteriol 43, 120-124.

Brosius, J., Palmer, M. L., Kennedy, P. J. \& Noller, H. F. (1978). Complete nucleotide sequence of a $16 \mathrm{~S}$ ribosomal RNA gene from Escherichia coli. Proc Natl Acad Sci U S A 75, 4801-4805.

Budzikiewicz, H. (1997). Siderophores of fluorescent pseudomonads. Z Naturforsch 52C, 713-720.

Champion, A. B., Barrett, E. L., Palleroni, N. J., Soderberg, R. L., Kunisawa, R., Contopoulou, R., Wilson, A. C. \& Doudoroff, M. (1980). Evolution in Pseudomonas fluorescens. J Gen Microbiol 120, 485-511.

Coroler, L., Elomari, M., Hoste, B., Gillis, M., Izard, D. \& Leclerc, H. (1996). Pseudomonas rhodesiae sp. nov., a new species isolated from natural mineral waters. Syst Appl Microbiol 19, 600-607.

Crosa, J. H., Brenner, D. J. \& Falkow, S. (1973). Use of a single-strand specific nuclease for analysis of bacterial and plasmid deoxyribonucleic acid homo- and hetero-duplexes. J Bacteriol 115, 904-911.

Dabboussi, F., Hamze, M., Elomari, M., Verhille, S., Baida, N., Izard, D. \& Leclerc, H. (1998). A numerical study of fluorescent Pseudomonas strains isolated from three Lebanese spring waters. J Europ Hydrol 28, 325-338.

Dabboussi, F., Hamze, M., Elomari, M., Verhille, S., Baida, N., Izard, D. \& Leclerc, H. (1999a). Taxonomic study of bacteria isolated from Lebanese spring waters: proposal for Pseudomonas cedrella sp. nov. and P. orientalis sp. nov. Res Microbiol 150, 303-316.

Dabboussi, F., Hamze, M., Elomari, M., Verhille, S., Baida, N., Izard, D. \& Leclerc, H. (1999b). Pseudomonas libanensis sp. nov., a new species isolated from Lebanese spring waters. Int J Syst Bacteriol 49, 1091-1101.

De Ley, J. (1970). Reexamination of the association between melting point, buoyant density, and chemical base composition of deoxyribonucleic acid. J Bacteriol 54, 738-754.

De Vos, P. \& De Ley, J. (1983). Intra- and intergeneric similarities of Pseudomonas and Xanthomonas ribosomal ribonucleic acid cistrons. Int $J$ Syst Bacteriol 33, 487-509.

De Vos, P., Kersters, K., Falsen, E., Pot, B., Gillis, M., Segers, P. \& De Ley, J. (1985). Comamonas Davis and Park 1962 gen. nov., nom. rev. emend., and Comamonas terrigena Hugh 1962 sp. nov., nom. rev. Int $J$ Syst Bacteriol 35, 443-453. 
De Vos, P., Van Landshoot, A., Segers, P. \& 9 other authors (1989). Genotypic relationships and taxonomic localization of unclassified Pseudomonas and Pseudomonas-like strains by deoxyribonucleic acid : ribosomal ribonucleic acid hybridizations. Int J Syst Bacteriol 39, 35-49.

Edwards, U., Rogall, T., Blöcker, H., Emde, M. \& Böttger, E. (1989). Isolation and direct complete nucleotide determination of entire genes. Characterization of a gene coding for $16 \mathrm{~S}$ ribosomal RNA. Nucleic Acids Res 17, 7843-7853.

Elomari, M., Coroler, L., Hoste, B., Gillis, M., Izard, D. \& Leclerc, H. (1996). DNA relatedness among Pseudomonas strains isolated from natural mineral waters and proposal of Pseudomonas veronii sp. nov. Int J Syst Bacteriol 46, 1138-1144.

Elomari, M., Coroler, L., Verhille, S., Izard, D. \& Leclerc, H. (1997). Pseudomonas monteilii sp. nov., isolated from clinical specimens. Int $J$ Syst Bacteriol 47, 846-852.

Felsenstein, J. (1985). Confidence limits on phylogenies: an approach using the bootstrap. Evolution 39, 783-791.

Fox, G. E., Stackebrandt, E., Hespelle, R. B. \& 15 other authors (1980). The phylogeny of procaryotes. Science 209, 457-463.

Gavini, F., Holmes, B., Izard, D., Beji, A., Bernigaud, A. \& Jakubczak, E. (1989). Numerical taxonomy of Pseudomonas alcaligenes, $P$. pseudoalcaligenes, $P$. mendocina, P. stutzeri and related bacteria. Int J Syst Bacteriol 39, 135-144.

Gavini, F., Pourcher, A.-M., Neut, C., Monget, D., Romond, C., Oger, C. \& Izard, D. (1991). Phenotypic differentiation of bifidobacteria of human and animal origins. Int J Syst Bacteriol 41, 548-557.

Gilardi, G. L. (1972). Infrequently encountered Pseudomonas species causing infections in humans. Ann Intern Med 72, 211-215.

Grimont, F. \& Grimont, P. A. D. (1986). Ribosomal ribonucleic acid gene restriction patterns as potential taxonomic tools. Ann Inst Pasteur/Microbiol 137B, 165-175.

Grimont, P. A. D., Popoff, M. Y., Grimont, F., Coynault, C. \& Lemelin, M. (1980). Reproducibility and correlation study of three deoxyribonucleic acid hybridization procedures. Curr Microbiol 4, 325-330.

Grimont, P. A. D., Vancanneyt, M., Lefèvre, M., Vandemeulebroecke, K., Vauterin, L., Brosch, R., Kersters, K. \& Grimont, F. (1996). Ability of biolog-100 systems to reveal the taxonomic diversity of the pseudomonads. Syst Appl Microbiol 19, 510-527.

Holmes, B., Steigerwalt, A. G., Weaver, R. E. \& Brenner, D. J. (1987). Chryseomonas luteola comb. nov. and Flavimonas oryzihabitans gen. nov., comb. nov., Pseudomonas-like species from human clinical specimens and formerly known, respectively, as groups Ve-1 and Ve-2. Int J Syst Bacteriol 37, 245-250.

Kersters, K., Ludwig, W., Vancanneyt, M., De Vos, P., Gillis, M. \& Schleifer, K. H. (1996). Recent changes in the classification of the pseudomonads: an overview. Syst Appl Microbiol 19, 465-477.

Kimura, M. (1980). A simple method for estimating evolutionary rates of base substitutions through comparative studies of nucleotide sequences. J Mol Evol 16, 111-120.

Koedam, N., Wittouck, E., Gaballa, A., Gillis, A., Höfte, M. \& Cornelis, P. (1994). Detection and differentiation of microbial siderophores by isoelectric focusing and chrome azurol S overlay. Biometals $\mathbf{7}$, 287-291.

Lane, D. J. (1991). 16S/23S rRNA sequencing. In Nucleic Acid Techniques in Bacterial Systematics, pp. 115-175. Edited by E. Stackebrandt \& M. Goodfellow. Chichester: John Wiley.

Meyer, J. M. \& Stintzi, A. (1998). Iron metabolism and siderophores in Pseudomonas and related species. In Biotechnology Handbooks 10, Pseudomonas, pp. 201-243. Edited by T. C. Montie. New York: Plenum.

Meyer, O., Stackebrandt, E. \& Auling, G. (1993). Reclassification of ubiquinone Q-10 containing carboxydotrophic bacteria: transfer of '(Pseudomonas) carboxydovorans' $\mathrm{OM}^{\mathrm{T}}$ to Oligotropha, gen. nov., as Oligotropha carboxydovorans, comb. nov., transfer of '(Alcaligenes) carboxydus' DSM $1086^{\mathrm{T}}$ to Carbophilus, gen. nov., as Carbophilus carboxidus, comb. nov., transfer of '(Pseudomonas) compransoris' DSM
$1231^{\mathrm{T}}$ to Zavarzinia gen. nov., as Zavarzinia compransoris, comb. nov., and emended descriptions of the new genera. Syst Appl Microbiol 16, 390-395.

Meyer, J.-M., Stintzi, A., De Vos, D., Cornelis, P., Tappe, R., Taraz, K. \& Budzikiewicz, H. (1997). Use of siderophores to type pseudomonads: the three Pseudomonas aeruginosa pyoverdine systems. Microbiology 143, 35-43.

Moore, E. R. B., Mau, M., Arnsceidt, A., Böttger, E. C., Hutson, R. A., Collins, M. D., Van De Peer, Y., De Wachter, R. \& Timmis, K. N. (1996). The determination and comparison of the 16S rRNA gene sequences of species of the genus Pseudomonas (sensu stricto) and estimation of the natural intrageneric relationships. Syst Appl Microbiol 19, 478-492.

Nakagawa, Y., Sakane, T. \& Yokota, A. (1996). Transfer of 'Pseudomonas riboflavina' (Foster 1944), a Gram-negative, motile rod with long-chain 3-hydroxy fatty acids, to Devosia riboflavina gen. nov., sp. nov., nom. rev. Int J Syst Bacteriol 46, 16-22.

Palleroni, N. J. (1984). Genus I. Pseudomonas Migula 1984, 237 $7^{\mathrm{AL}}$ (Nom. Cons. Opin. 5, Jud. Comm. 1952, 237). In Bergey's Manual of Systematic Bacteriology, vol. 1, pp. 141-199. Edited by N. R. Krieg \& J. G. Holt. Baltimore: Williams \& Wilkins.

Palleroni, N. J. (1992). The prokaryotes. In A Handbook on the Biology of Bacteria: Ecophysiology, Isolation, Identification, Applications, pp. 3086-3103. Edited by A. Balows, H. G. Trüper, M. Dworkin, W. Harder \& K.-H. Schleifer. New York: Springer.

Palleroni, N. J. \& Bradbury, J. F. (1993). Stenotrophomonas, a new bacterial genus for Xanthomonas maltophilia (Hugh 1980) Swings et al. 1983. Int J Syst Bacteriol 43, 606-609.

Palleroni, N. J., Kunisawa, R., Contopoulou, R. \& Doudoroff, M. (1973). Nucleic acid homologies in the genus Pseudomonas. Int J Syst Bacteriol 23, 333-339.

Pedersen, M. M., Marso, E. \& Pickett, M. J. (1970). Non-fermentative bacilli associated with man. 3. Pathogenicity and antibiotic susceptibility. Am J Clin Pathol 54, 178-192.

Rogers, K. B. (1960). Pseudomonas infections in children's hospital. J Appl Bacteriol 23, 533-537.

Saitou, N. \& Nei, M. (1987). The neighbor-joining method: a new method for reconstructing phylogenetic trees. Mol Biol Evol 4, 406-425.

Segers, P., Vancanneyt, M., Pot, B., Torck, U., Hoste, B., Dewettinck, D., Falsen, E., Kersters, K. \& De Vos, P. (1994). Classification of Pseudomonas diminuta Leifson and Hugh 1954 and Pseudomonas vesicularis Büsing, Döll, and Freytag 1953 in Brevundimonas gen. nov. as Brevundimonas diminuta comb. nov. and Brevundimonas vesicularis comb. nov., respectively. Int J Syst Bacteriol 44, 499-510.

Stackebrandt, E. \& Goebel, B. M. (1994). Taxonomic note: a place for DNA-DNA reassociation and $16 \mathrm{~S}$ rRNA sequence analysis in the present species definition in bacteriology. Int J Syst Bacteriol 44, 846-849.

Stanier, R. Y., Palleroni, N. J. \& Doudoroff, N. (1966). The aerobic pseudomonads: a taxonomic study. J Gen Microbiol 43, 159-271.

Sutter, V. L. (1968). Identification of Pseudomonas species isolated from hospital environment and human sources. Appl Microbiol 16, 1532-1538

Thompson, J. D., Gibson, T. J., Plewniak, F., Jeanmougin, F. \& Higgins, D. G. (1997). The CLUSTAL $x$-Windows interface: flexible strategy for multiple sequence alignment by quality tools. Nucleic Acids Res 25, 4876-4882.

Urakami, T., Araki, H., Oyanagi, H., Suzuki, K. I. \& Komogata, K. (1992). Transfer of Pseudomonas aminovorans (den Dooren de Jong 1926) to Aminobacter gen. nov. as Aminobacter aminovorans comb. nov. and description of Aminobacter aganoensis sp. nov. and Aminobacter niigataensis sp. nov. Int J Syst Bacteriol 42, 84-92.

Vancanneyt, M., Torck, U., Dewettinck, D., Vaerewijck, M. \& Kersters, K. (1996). Grouping of pseudomonads by SDS-PAGE of whole-cell proteins. Syst Appl Microbiol 19, 556-568.

Von Graevenitz, A. \& Weinstein, J. (1971). Pathogenic significance of Pseudomonas fluorescens and Pseudomonas putida. Yale J Biol Med 43, 265-273. 
Wayne, L. G., Brenner, D. J., Colwell, R. R. \& 9 other authors (1987). International Committee on Systematic Bacteriology. Report of the ad hoc committee on reconciliation of approaches to bacterial systematics. Int J Syst Bacteriol 37, 463-464.

Wen, A., Fegan, M., Hayward, C., Chakraborty, S. \& Sly, L. I. (1999). Phylogenetic relationships among members of the Comamonadaceae, and description of Delftia acidovorans (den Dooren de Jong 1926 and Tamaoka et al. 1987) gen. nov., comb. nov. Int J Syst Bacteriol 49, 567-576.

Willems, A., Busse, J., Goor, M. \& 8 other authors (1989). Hydrogenophaga, a new genus of hydrogen-oxidizing bacteria that includes Hydrogenophaga flava comb. nov. (formerly Pseudomonas flava), Hydrogenophaga palleroni, (formerly Pseudomonas palleroni), Hydrogenophaga pseudoflava (formerly Pseudomonas pseudoflava and 'Pseudomonas carboxydoflava'), and Hydrogenophaga taeniospiralis (formerly Pseudomonas taeniospiralis). Int J Syst Bacteriol 39, 319-333.

Willems, A., Falsen, E., Pot, B., Jantzen, E., Hoste, B., Vandamme, P., Gillis, M., Kersters, K. \& De Ley, J. (1990). Acidovorax, a new genus for Pseudomonas facilis, Pseudomonas delafieldii, E. Falsen (EF) group 13, EF group 16, and several clinical isolates, with the species Acidovorax facilis comb. nov., Acidovorax delafieldii comb. nov., and Acidovorax temperans sp. nov. Int J Syst Bacteriol 40, 384-398.
Willems, A., Goor, M., Thielemans, S., Gillis, M., Kersters, K. \& De Ley, J. (1992). Transfer of several phytopathogenic Pseudomonas species to Acidovorax as Acidovorax avenae subsp. avenae subsp. nov., comb. nov., Acidovorax avenae subsp. citrulli, Acidovorax avenae subsp. cattleyae, and Acidovorax konjaci. Int J Syst Bacteriol 42, 107-119.

Yabuuchi, E., Yano, I., Oyaizu, H., Hashimoto, Y., Ezaki, T. \& Yamamoto, H. (1990). Proposals of Sphingomonas paucimobilis gen. nov. and comb. nov., Sphingomonas parapaucimobilis sp. nov., Sphingomonas yanoikuyae sp. nov., Sphingomonas adhaesiva sp. nov., Sphingomonas capsulata comb. nov., and two genospecies of the genus Sphingomonas. Microbiol Immunol 34, 99-119.

Yabuuchi, E., Kosako, Y., Oyaizu, H., Yano, I., Hotta, H., Hashimoto, Y., Ezaki, T. \& Arakawa, M. (1992). Proposal of Burkholderia gen. nov. and transfer of seven species of the genus Pseudomonas homology group II to the new genus, with the type species Burkholderia cepacia (Palleroni and Holmes 1981) comb. nov. Microbiol Immunol 36, 1251-1275.

Yabuuchi, E., Kosako, Y., Yano, I., Hotta, H. \& Nishiuchi, Y. (1995). Transfer of two Burkholderia and an Alcaligenes species to Ralstonia gen. nov.: proposal of Ralstonia pickettii (Ralston, Palleroni and Doudoroff 1973) comb. nov., Ralstonia solanacearum (Smith 1896) comb. nov., and Ralstonia eutropha (Davis 1969) comb. nov. Microbiol Immunol 39, 897-904. 